\title{
THE EFFECT OF ROLE PLAYING TYPE OF COOPERATIVE MODEL ON THE INDONESIAN LEARNING OUTCOMES OF ELEMENTARY STUDENTS
}

\author{
Andi Wibowo', Siti Masruro ${ }^{2}$ \\ 1,2 Universitas Islam Raden Rahmat Malang \\ Email: andi21harto@gmail.com
}

\begin{abstract}
This study aims to determine the effect of the role playing type of cooperative model on student learning outcomes in the Indonesian language learning process. This study used experimental research design. Subject of this study are student in fourth grades at Kemantren 1 Elementary School. The researches variables consist of independent variable that is role playing models and lecture methods. Independent variable is the result of learning Indonesian. Students in fourth A grade as an experimental class and Fourth B grade as a control class. The instrument used in this study is the result of learning process. Data analysis techniques for cognitive domain using several steps. They are descriptive analysis, prerequisite test of normality and homogeneity, and hypothesis testing using t-test. The results showed that the role playing model influenced the learning outcomes of Indonesian language in fourth grade students at Kemantren 1 Elementary School. The average Indonesian learning in control class with the lecture method was 67,78 while the Indonesian learning outcomes in experimental class with role playing models was 74,07 . Process data analysis of two groups using t-test results obtained t value of $2.896>\mathrm{t}$ table of 2.006. That is show that there are some influences in learning role playing models toward the result of Indonesian language study.
\end{abstract}

Keywords: role playing, learning outcome, Indonesian learning

(c) (1) This work is licensed under Creative Commons Attribution License 4.0 CC-BY International license

\section{INTRODUCTION}

The progress of the world of education and science cannot be separated from the ability of educators to transfer knowledge to their students. The development of science and technology today requires teachers to become more professional educators in the learning process. Professional educators make learning more quality and better so that it is in accordance with the times. A special knowledge and involvement of various competent parties in the world of education to create professional educators. Education is a process for a person to gain knowledge, experience and behavior that shape a person's personal good or bad (Ernani, 2016). In addition, the role of education for a person is also an important factor in obtaining students' 
abilities and skills to solve problems in learning. One of the problems that occur in students is in learning Indonesian. Learning Indonesian is a long journey process that every student goes through in learning Indonesian or a second language. The competencies in learning Indonesian include listening, speaking, reading, and writing. One of the speaking tasks that teachers need to design for their students is to tell a story dramatically or play the role of a character in a film, play or television show. The current lesson is playing the characters in the poems or stories. Indonesian language learning currently only reads without any direct role from students making lessons less interesting. Teachers and students in the 2013 curriculum are required to be more active, creative in the learning process. Teachers must apply methods that are adapted to the material presented in order to improve student learning outcomes.

Based on the results of observations carried out by researchers by conducting interviews on 5 November 2018 to teachers and fourth grade students at SDN Kemantren 1. The results of the interviews turned out that the average value of student learning outcomes in Indonesian language learning had not reached the minimum criteria, because students had difficulty understanding the material presented by the teacher. Students during the Indonesian language learning process only read without practicing it directly in accordance with the learning material, and student's interest in Indonesian subjects was very high but difficult to understand the material. The method used by the teacher during learning is the conventional method. In the conventional method which is only centered on the teacher. While students only listen to the explanation of the material from the teacher, so it does not stimulate student activity. This happens because teachers have difficulty in carrying out active Indonesian learning activities. While the 2013 curriculum which applies tematic learning requires students to be active in learning activities.

Therefore, one way to overcome the gap above is by using the Role Playing model. Role playing is a method that involves the interaction of 2 or more people about a topic or situation. Role Playing model in the learning process that emphasizes emotional involvement and sensory observation into a real problem. The teacher arranges and facilitates the role play and then it is followed up with discussion. During the game, other students who did not participate were given the task of observing, summarizing hidden messages and evaluating role plays. The advantage of this method is that all students can participate and have the opportunity to test their ability to work together (Hamdani, 2011). Through the use of the Role Playing model, students are expected to be active in learning. Also able to think critically and be able to solve problems or problems in Indonesian language material, so that students obtain satisfactory learning outcomes.

Several studies have shown that the Role Playing model has a significant effect on student learning outcomes. These studies include study conducted by Sumarni (2014) with the title The Effect of Role Playing Method on Learning Outcomes of Class V Elementary School Students "that the Role Playing method has a significant effect on student learning outcomes. The study conducted by Wahyudin (2014) entitled "The Effect of Role Playing Method on Student Learning Outcomes in Class IV PKN Learning" that the Role Playing method has a considerable influence on student learning outcomes. Based on the explanation above, the researcher is interested in conducting a research entitled "The Effect of the Role Playing Model Cooperative Method on the Learning Outcomes of Elementary School Students in Indonesian Language Learning". Cooperative learning is a form of learning in which students learn and 
work in collaborative small groups whose members consist of four to six people with heterogeneous group structures (Anggraeni, 2016). In addition, cooperative learning as mutual cooperation learning, namely a learning system that provides opportunities for students to cooperate with other students in structured tasks (Arifin, 2016).

Based on several definitions of cooperative learning that have been stated above, cooperative learning is the formation of group members that are arranged in such a way that students can work together, interact, and exchange ideas in learning to achieve predetermined learning goals. Pratiwi (2016) said that the role playing model is a way of mastering lesson materials through the development of students' imagination and appreciation in which there are rules, goals, and elements of pleasure in carrying out the teaching and learning process. Hendy (2016) argues that students are directed to obtain learning opportunities, namely expressing feelings, thoughts, ideas accompanied by various movements so that they can be understood by others. Based on several definitions of the Role Playing model that have been stated above, the Role Playing model is a way of mastering the subject matter carried out by students in developing imagination and appreciation in the learning process in which there are rules, goals, and elements of affection. Students in the learning process must be active, because without activity, the learning process is impossible.

According to Rifa'i \& Anni (2009) learning outcomes are changes in behavior obtained by students after experiencing learning activities. Learning outcomes are changes in behavior that are obtained after experiencing activities. According to Sutrimo (2015), learning outcomes are the occurrence of changes in behavior in a person that can be observed and measured in the form of knowledge, attitudes and skills. Based on some understanding of learning outcomes that have been put forward above, the learning outcomes referred to in this study are changes in behavior caused by completing the learning process with the cooperative method of the Role Playing model in the form of student learning outcomes. The purpose of this study is to determine the effect of the Role Playing method on student learning outcomes in the Indonesian language learning process. In this study, the formulation of the hypothesis tested in this study was to improve student learning outcomes in Indonesian subjects using the Role Playing method better than students who received learning using conventional approaches or just reading without any direct role from students. This study will prove which learning model is more effective in improving student learning outcomes in Indonesian subjects. Is the increase in learning outcomes using the Role Playing method better than students who get learning with a conventional approach or just reading without any direct role from students.

\section{METHOD}

\subsection{Research Design}

The research method used is a quasi experimental design. In this model there is an experimental group and a control group, where the sampling is saturated. The independent variables in this study were the Role Playing model and the lecture method, while the dependent variable was student learning outcomes. 


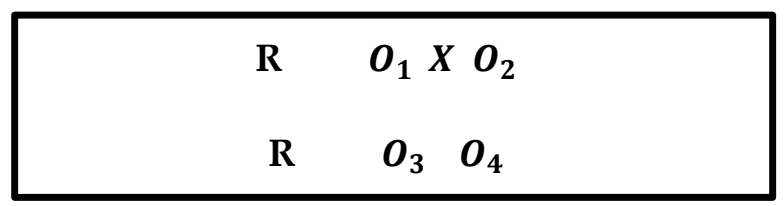

Figure 1. Research Design (Sugiyono, 2016)

\subsection{Samples/Participants}

The sampling technique in this study included population sampling, namely all students of SD Negeri Kemantren 1 and the target population, namely students in class IVA and IVB at SD Negeri Kemantren 1 who were active, and the samples in this study included the experimental group, namely class IVA students, totaling 27 students. who received learning with the Role Playing model and the control group, namely class IVB students, totaling 27 students who did the conventional model.

\subsection{Instruments}

The instruments in this study include the validity of the learning outcomes test instrument in the form of 10 multiple choice questions, the assessment criteria used are a score of 1 if the answer is correct and 0 if the answer is wrong. The testing of the test instrument was carried out in class IV of the State Elementary School 02 Pakisjajar. Test the validity in this study using SPSS for Windows 21. From the data from the test results of the test instrument, the researcher uses valid questions that can be used while invalid questions are replaced with other questions because if the invalid questions are omitted, the number of questions is reduced. The reliability test results obtained from the instrument test at SDN 02 Pakisjajar is 500. So it can be said to be reliable and feasible to be used in research.

\subsection{Data analysis}

The data collection techniques used in this study are: to support the purposes of analyzing the data for this study, researchers need a number of supporting data from inside and outside the SDN 1 Kemantren class. Data collection techniques are also in the form of learning outcomes tests, observations, and documentation. Data analysis techniques in this study include a) descriptive analysis by calculating the mean, median, mode, standard deviation, minimum value and maximum value with the help of the IBM SPSS 21 program, b) score categorization criteria, c) prerequisite test in the form of normality test, homogenity test, and d) hypothesis testing.

\section{FINDINGS AND DISCUSSION}

\subsection{Findings}

The treatment was given on Thursday, July 182019 at 1-2 hours for class IVA (experimental class) and Wednesday July 172019 at 4-5 for class IVB (control class). In this study, researchers obtained data from the results of the Pre Test given to students before being treated and Post Test given to students after being treated. Both of these tests serve to measure the effectiveness of the learning program.

The pre test in the experimental class has an average value or mean of 58.15 , mode of 60 , median of 60.00, standard deviation of 9214, minimum value of 40 and maximum value of 80 . 
Pre test in control class has an average value -average/mean of 54.44, median of 50.00, standard deviation of 9337, minimum value of 40 and maximum value of 80 . Post test in the experimental class has an average value or mean of 74.07, median of 70 0.000, standard deviation of 9214, minimum value of 60 and maximum value of 100. Post test in the control class has an average value of 67.78 , median of 70.00, standard deviation of 6980 , minimum value of 60 and a maximum value of 80 .

Normality test with the help of SPSS for windows 21 program. The formula used is Kolmogorov-Smirnov as follows:

Table 1. Normality test for experiment class and control class

\begin{tabular}{llll}
\hline Data & $\boldsymbol{s i g}_{\text {score }}$ & $\boldsymbol{s i g}_{\mathbf{m i n}}$ & Description \\
\hline Experimental class & 0,061 & 0,05 & normal distribution \\
& & data & \\
Control class & 0,131 & 0,05 & normal distribution \\
& & data & \\
\hline
\end{tabular}

The results of the normality test stated that the data were normally distributed. In Table 2 show that the data is homogeny. This is indicated by $\boldsymbol{s i g}$ score $>0,05$ which means the data is normally distributed.

Table 2. Test of homogeneity of experimental class and control class

\begin{tabular}{lllc}
\hline Data & sig & score & sig \\
Pre Test & 0,668 & 0,05 & Description \\
Post Test & 0,368 & 0,05 & homogeny variant \\
\hline
\end{tabular}

\begin{tabular}{|c|c|c|c|c|c|c|c|c|c|}
\hline \multicolumn{10}{|c|}{ Independent Samples Test } \\
\hline & \multicolumn{2}{|c|}{$\begin{array}{l}\text { Levene's Testifor Eguality of } \\
\text { Variances }\end{array}$} & \multicolumn{7}{|c|}{ t-test for Equality of Means } \\
\hline & \multirow[b]{2}{*}{$F$} & \multirow[b]{2}{*}{ Sig. } & \multirow[b]{2}{*}{$t$} & \multirow[b]{2}{*}{ df } & \multirow[b]{2}{*}{ Sig. (2-ataleded) } & \multirow{2}{*}{$\begin{array}{c}\text { Mean } \\
\text { Difference }\end{array}$} & \multirow{2}{*}{$\begin{array}{l}\text { Std. Error } \\
\text { Difference } \\
\end{array}$} & \multicolumn{2}{|c|}{$\begin{array}{l}95 \% \text { Confidence Interval of the } \\
\text { Difference }\end{array}$} \\
\hline & & & & & & & & Lower & Upper \\
\hline hasil belajar Equal variances assumed & .824 & .368 & -2.896 & 52 & .006 & -6.2963 & 2.1742 & -10.6592 & -1.9334 \\
\hline Equal variances not assumed & & & -2.896 & 49.243 & .006 & -6.2963 & 2.1742 & -10.6650 & -1.9276 \\
\hline
\end{tabular}

Figure 2. Output of independent samples t-test

In Figure 1, it can be seen that the negative t-count in the table above is -2.896 which is not an error. However, this negative t-count is caused because the average value of learning outcomes in the control Post Test group (group 1) is lower than the average value of learning outcomes in the experimental Post Test group (group 2). So if you use decision making in the independent sample $\mathrm{t}$ test through a comparison between the $\mathrm{t}$-count value and the $\mathrm{t}$-table, then the $t$-count value can be positive, namely 2.896 . The calculated $t$ value is $2.896>t$ table is 2.006 , so as the basis for the decision above, it can be concluded that $H_{0}$ is rejected and $H_{a}$ is accepted. So it can be concluded that there is an effect of the use of the Role Playing model on student learning outcomes of SDN Kemantren 1. 
In the learning process at the SDN Kemantren 1, the teacher has applied conventional learning methods. However, this study use the Role Playing model to be applied in the school. Things that need to be considered in implementing the Role Playing model are determining the topic, determining the cast, and implementing Role Playing. The learning experience obtained in this model is that students are able to cooperate with other students and actively communicate with fellow students to achieve predetermined learning goals. This study aims to determine whether the Role Playing model has an effect or not on student learning outcomes in Indonesian class IV subjects at SDN Kemantren 1, Malang Regency. The design used in the Pre Test-Post Test Control Group Design. In this design, two groups were compared, namely the experimental group and the control group. Sampling in this study is saturated sampling. Because, all members of the population are used as samples. In this design, pre-test and post-test were used in both classes.

This study was carried out in stages, namely the first stage, namely the preparation stage. At this preparatory stage, several things were carried out, namely, analyzing the topic of the material, compiling a Learning Implementation Plan, preparing research instruments and developing test questions. The second stage, namely the implementation stage, was carried out several things, namely, giving a Pre-Test to determine mastery of concepts and to find out the students' initial abilities before taking Indonesian language subjects. Applying the Role Playing model in the experimental class and applying the conventional methods commonly used by the teachers of SDN Kemantren 1 in teaching in the control class. Furthermore, giving Post Test questions to both classes, namely, the experimental class and the control class to see the improvement of the material, after students take part in the learning. The third stage, namely the final stage in the form of a description of the data in the previous discussion, the results of the Pre Test in the experimental class obtained an average value (X) of 58.15 and an average value (X) of the control class of 54.44. However, after being treated with Post Test results, the experimental class reached an average value $(\mathrm{X})$ of 74.07 and the control class of 67.78.

The results of the normality test showed that the experimental class Sig count was 0.061 and Sig min was 0.05. Based on the predetermined criteria, if the calculated significance value is $>0.05$, it can be concluded that the data is normally distributed. The experimental class shows $0.061>0.05$ then the data is normally distributed. And the results of the normality test showed that the control class Sig count was 0.131 and Sig min was 0.05. Based on the criteria that have been determined, if the arithmetic significance value is $>0.05$, it can be concluded that the data is normally distributed. The control class shows a sig count of $0.131>0.05$, so it is normally distributed. Pre Test homogeneity test of student learning outcomes between the experimental class and control class showed Sig count 0.668 and Sig table of 0.05 and the Post Test homogeneity tested student learning outcomes between the experimental class and control class showed Sig count of 0.368 and Sig table of 0.05 . The homogeneity test results from the results of the two classes that the data have the same variance. This is indicated by Sig count $>0.05$ which means the data has the same variance. Meanwhile, from the results of data analysis using the t-test Post Test, the t-count value is 2.896 and the t-table is 2.006 because $\mathrm{t}$-count $>\mathrm{t}$-table (2.896>2.006) then $\mathrm{H}_{0}$ is rejected and $\mathrm{Ha}$ is accepted, which means that there is an effect of using the Role Playing model on learning outcomes. Students of SDN Kemantren 1. As the results of 
the t-test above can be explained that $\mathrm{Ha}$ is accepted, which means that there is a significant difference in student learning outcomes using conventional methods in Indonesian learning.

\subsection{Discussion}

The occurrence of the influence of Role Playing learning on Indonesian language learning outcomes is caused by the characteristics of Role Playing learning itself in which students learn in groups. By studying in groups can make it easier for students to interact with their friends, facilitate the division of tasks, train the nature of being responsible for their duties and roles in the Role Playing method, and make it easier to understand themselves and others how to perform existing roles (Ismania, 2015).

Various kinds of research show that role playing models can improve learning outcomes. Research conducted by Sutiyani, et al (2015) proved that the role playing model on the theme of global warming and its impact on the ecosystem has a positive effect on students' cognitive learning outcomes by $48.34 \%$ and has a positive effect on students' affective and psychomotor learning outcomes. Setyowati's research (2020) proves that the role playing learning model has an effect on student learning outcomes in Indonesian subjects with theme 8 fiction story material for grade IV Elementary School. Anwar (2018) proves that there is an effect of the application of the role playing learning model on learning outcomes in social studies subjects for fifth grade elementary school students. Research that has been carried out by Sumarni (2014) and Wahyudin (2014) which proves that the role playing learning model is effective for improving learning outcomes.

The role playing model has a positive effect on learning outcomes due to the various advantages of this model. The Role Playing model is a learning model that involves interaction between two or more students about a topic or situation. Students perform their respective roles according to the character played. They interact with each other in performing an open role. The Role Playing model is a way of mastering the subject matter through the development of students' imagination and appreciation. The development of imagination and appreciation is carried out by students by playing them as living figures or inanimate objects. Through this model, interest in observing, drawing conclusions, applying and communicating can be developed. Role playing is a planned learning goal designed to achieve specific educational goals (Hendy, 2016). The result of the role-maker's interactions with scenarios, other individuals, or friends in the class, or both learning something about a specific person, problem or situation in the subject. Role playing Role playing is often one of the applications of application based on experience. Role playing is designed to help students learn social values that reflect within themselves, foster empathy for others, and try to develop social skills (Alfaruki, 2018).

The advantage of role playing is that all students can participate and have the opportunity to test their ability to work together. In this model there are several advantages. First, games are easy inventions and can be used in different situations and times. Second, the teacher can evaluate the understanding of each student through observations while playing the game. Third, students are free to make decisions and express themselves as a whole. Fourth, the game is a fun learning experience for children (Hamdani, 2011). The advantages of the role playing model involve all students participating, having the opportunity to advance their ability to work together. Students can also learn to use language properly and correctly. 


\section{CONCLUSIONS}

\subsection{Conclusion}

Based on the results of the analysis and statistical research described above, it can be concluded that student learning outcomes in Indonesian subjects have the influence of the Role Playing model and conventional methods, seen from the average value of the experimental class 74.07 , while the average value of the control class is 67.78 , the results of the $t$ test calculation show the $\mathrm{t}$ count $>\mathrm{t}$ table $(2.896>2.006)$, it can be concluded that the Role Playing model has an effect on student learning outcomes in Indonesian subjects and there are significant learning outcomes between groups of students who learn to use the model. Role Playing with groups of students who learn to use conventional methods in Indonesian subjects with an average experimental class > control class $(74.07>67.78)$.

\subsection{Suggestions}

The process of learning Indonesian cannot be separated from the lecture method, but lectures should not dominate continuously in every lesson. The teacher in applying the Role Playing method can actually not only be done in the classroom, the use of this method can also be done outside the classroom. The Role Playing method will be more interesting if it uses the appropriate media. Students at the time of implementing the Role Playing Method in learning should master the material presented and show more appreciation of the role so that the learning situation becomes more interesting and fun.

For further researchers, it is better to be able to compare the role playing model with other learning models so that the role playing model can be more proven to improve learning outcomes. In addition, further researchers can also apply role playing models in other subject areas besides Indonesian.

\section{REFERENCES}

Aggraeni, W. (2016). Model Pembelajaran Kooperatif. (online). https://jurnal.repository.unpas.a c.id diakses pada tanggal 21 Agustus 2019.

Alfaruki, M. (2018). Metode Bermain Peran (Role Playing). (online). https://jurnal.repo.iaintulungagung.ac.id diakses pada tanggal 21 Agustus 2019.

Anwar, H., Syahribulan, Basri, M. (2018). Pengaruh Penerapan Model Pembelajaran Role Playing Terhadap Hasil Belajar Ilmu Pengetahuan Sosial (IPS) Pada Murid Kelas V. Jurnal Kajian Pendidikan Dasar, 3 (2): 486-495.

Aqliyah, I. (2015). Pengaruh Penerapan Role Playing Terhadap Hasil Belajar Siswa Kelas V MI Pada Pembelajaran IPS. (online). https.//jurnal.uika.ac.id diaskses pada tanggal 29 Agustus 2019.

Arifin, A. (2016). Pembelajaran Kooperatif. (online). https://Jurnal.repo.Iain-tulungagung.ac.id diakses pada tanggal 21 Agustus 2019. 
Ernani. (2016). Pengaruh Metode Role Playing Terhadap Keterampilan Berbicara Siswa Pada Mata Pelajaran Bahasa Indonesia Kelas V di Madrasah Ibtidaiyah Wathoniyah Palemba $n g$. (online). https://jurnal.radenfatah.ac.id/index.php/jip/article/view/1072/906 diakses pa da tanggal 18 November 2018.

Hamdani. (2011). Strategi Belajar Mengajar. Bandung: Pustaka Setia.

Hendy, M. (2016). Pembelajaran Bermain Peran. (online). https://jurnal.eprints.walisongo.ac.id diakses pada tanggal 21 Agustus 2019.

Pratiwi, M.E. (2014). Role Playing. (online). https://jurnal.eprints.ums.ac.id diakses pada tanggal 21 Agustus 2019.

Rifa'i, A., \& Anni, C.T. (2009). Psikologi Pendidikan. Semarang: Pusat Pengembangan MKU/M KDK LP3 Universitas Negeri Semarang.

Setyowati, D., Kartikasari, K., Nuryasana, E. (2020). Pengaruh Model Pembelajaran Role Playing Terhadap Hasil Belajar Bahasa Indonesia Siswa SDN Asemrowo II. Trapsila: Jurnal Pendidikan Dasar, 2 (1): 12-24.

Sugiyono. (2016). Statistik untuk penelitian. Bandung: Alfabeta.

Sumarni, M.L. (2014). Penggunaan Metode Role Playing Terhadap Hasil Pembelajaran Siswa Kelas V. (online). https://jurnal.untan.ac.id/index.php/jpdpb/article/download/6856/7063 diakses pada tanggal 18 November 2018.

Sutiyani, S., Nurhayati, S., \& Widiyatmoko, A. (2015). Pengaruh Model Pembelajaran Role Playing Pada Hasil Belajar Siswa Smp Kelas VII Tema Global Warming dan Dampaknya Bagi Ekosistem. Unnes Science Education Journal,4 (3): 951-945.

Sutrimo, U. (2015). Hasil Belajar. https://jurnal.repository.ump.ac.id diakses pada tanggal 21 Agustus 2019.

Wahyudin, F. (2014). Pengaruh Metode Role Playing Terhadap Hasil Belajar Peserta Didik Dal am Pembelajaran Pkn Kelas IV. (online). http://download.garuda.ristekdikti.go.id diakses pada tanggal 18 November 2018.

Winarti, T. (2016). Pengaruh Model Role Paying Terhadap Minat dan Hasil Belajar Siswa. (online). https://Jurnal.untan.ac.id diaskses pada tanggal 02 Agustus 2019. 